\title{
Effects of Cultivar and Plant Spacing on the Seasonal Water Requirements of Highbush Blueberry
}

\author{
David R. Bryla ${ }^{1}$ \\ U.S. Department of Agriculture, Agricultural Research Service, Horticultural Crops Research Unit, \\ 3420 NW Orchard Avenue, Corvallis, Oregon 97330 \\ Bernadine C. Strik \\ Department of Horticulture, Oregon State University, 4017 ALS, Corvallis, Oregon 97331
}

\begin{abstract}
AdDitional INDEX wORDS. Vaccinium corymbosum, irrigation, plant water potential, root distribution, soil water availability, water use efficiency

Abstract. Plant water requirements were investigated in three northern highbush blueberry (Vaccinium corymbosum L.) cultivars, Duke, Bluecrop, and Elliott, grown either at a high-density spacing of $0.45 \mathrm{~m}$ apart within rows or a more traditional spacing of $1.2 \mathrm{~m}$. Spacing between rows was $3.0 \mathrm{~m}$. As is typical for the species, each cultivar was shallowrooted with most roots located less than $0.4 \mathrm{~m}$ deep, and each was sensitive to soil water deficits with plant water potentials declining as low as $-1.6 \mathrm{MPa}$ within 5 to 7 days without rain or irrigation. Compared with traditional spacing, planting at high density significantly reduced dry weight and yield of individual plants but significantly increased total dry weight and yield per hectare. High-density planting also significantly increased total canopy cover and water use per hectare. However, although canopy cover (often considered a factor in water use) increased up to $\mathbf{2 4 6 \%}$, water use never increased more than $10 \%$. Because of more canopy cover at high density, less water penetrated the canopy during rain or irrigation (by overhead sprinklers), reducing both soil water availability and plant water potential in each cultivar and potentially reducing water use. Among cultivars, water use was highest in 'Duke', which used 5 to $10 \mathrm{~mm} \cdot \mathrm{d}^{-1}$, and lowest in 'Elliott', which used 3 to $5 \mathrm{~mm} \cdot \mathrm{d}^{-1}$. Peak water use in each cultivar was during fruit development, but water use after harvest declined sharply. Longer irrigation sets (i.e., longer run times) or alternative irrigation methods (e.g., drip) may be required when growing blueberry at high density, especially in cultivars with dense canopies such as 'Elliott'.
\end{abstract}

Proper irrigation management is critical for profitable blueberry production in many commercial growing regions, including the Pacific northwestern United States where $\approx 24,000 \mathrm{t}$ of the fruit is produced annually (U.S. Dept. of Agr., 2006). Without enough irrigation, $g_{\mathrm{S}}$ declines quickly in blueberry (Améglio et al., 2000), leading to less $\mathrm{CO}_{2}$ assimilation (Erb et al., 1991) and lower growth and production (Anderson et al., 1979; Cameron et al., 1989). However, too much irrigation often reduces root function (Davies and Wilcox, 1984), increases soil erosion and nutrient leaching (Starr et al., 2004), and potentially causes problems with fungal pathogens such as Botrytis cinerea Pers. and Phytophthora cinnamomi Rands (Caruso and Ramsdell, 1995; de Silva et al., 1999). Typically, 25 to $50 \mathrm{~mm}$ of water per week is recommended for blueberry (Strik et al., 1993), although actual water requirements will likely vary not only with the environmental conditions, but also with the cultural practices under which the crop is grown. Two such practices that have received little attention in the literature but have considerable potential to

Received for publication 10 Apr. 2006. Accepted for publication 19 Jan. 2007. Research was funded in part by the Northwest Center for Small Fruits Research and the Oregon Blueberry Commission.

Mention of trademark, proprietary product, or vendor does not constitute a guarantee or warranty of the product by the U.S. Dept. of Agriculture and does not imply its approval to the exclusion of other products or vendors that also may be suitable.

We thank Hannah Rempel, Nick Rivard, Gil Buller, Will Fummerton, and Rick Moes for technical assistance.

${ }^{1}$ Corresponding author. E-mail: brylad@onid.orst.edu. influence plant water use include planting density and choice of cultivar.

Many growers these days are planting highbush blueberry at higher densities (Strik and Yarborough, 2005) to increase yield per hectare and lower production costs (Moore et al., 1993; Strik and Buller, 2002, 2005). It is reasonable to expect that plants spaced close together will require more irrigation in a given area than those spaced further apart because higher plant populations generally produce more leaves and canopy cover per hectare (Holzapfel et al., 2004; Storlie and Eck, 1996). Yuste et al. (2004) recently found that increasing density in 5-year-old grapevines (Vitis vinifera L.) from 2645 to 3953 plants/ha increased water use by up to $6.5 \%$ with only a $6.2 \%$ increase in total dry matter. They attributed the increase primarily to more leaf development at high density. Depending on how much leaf production is affected by planting density in blueberry, growing at higher density could substantially increase its water requirements. In a 4-year study on 'Duke', 'Bluecrop', and 'Elliott' blueberry, Strik and Buller (2005) reported that total dry weight per hectare of wood, crown, and roots (but no leaves) was $218 \%$ to $562 \%$ higher when plants were spaced at $0.45 \mathrm{~m}$ than at $1.2 \mathrm{~m}$ within rows.

Water requirements often differ among cultivars (e.g., Buchanan et al., 1978). These differences may be the result of inherent morphologic and physiological features as well as phenologic factors such as timing of fruit development. Water use appears to be especially high during fruit ripening in blueberry. Mingeau et al. (2001) found that almost $55 \%$ of the total seasonal water requirements of 'Bluecrop' occurred in 
June and July during fruit ripening; once fruit were picked, its water requirements decreased to nearly half. Therefore, cultivars that ripen early in the season may have very different water requirements than those that ripen late in the season. Haman et al. (1997) reported that daily water use in an early-season cultivar of highbush blueberry was much higher than in two late-season cultivars of rabbiteye blueberry (Vaccinium ashei Reade). Identifying when and why water is most needed by different cultivars may help growers to better budget their irrigations and maximize production efficiency.

The objective of the present study was to determine the effects of cultivar and planting density on water requirements during irrigation of highbush blueberry. Three cultivars with different fruit-ripening periods were chosen for study. Each cultivar was planted either at a high-density spacing of $0.45 \mathrm{~m}$ apart within rows or at a more traditional spacing of $1.2 \mathrm{~m}$.

\section{Materials and Methods}

STUDY SITE. The study was conducted on a 0.15 -ha field of northern highbush blueberry established at the North Willamette Research and Extension Center, Aurora, Ore. in Oct. 1999. 'Duke', 'Bluecrop', and 'Elliott' were planted at the site on Willamette silt loam (fine-silty, mixed, mesic Pachic Ultic Argixerolls) soil fumigated with methyl bromide/chloropicrin. 'Duke' and 'Bluecrop' are the two most popular cultivars grown in the Pacific northwestern United States (Yang, 2002) and are typically harvested in late June and early July, respectively. 'Elliott' is a popular late-season cultivar often harvested in August. Each cultivar was obtained from a commercial nursery as 2-year-old container stock and spaced either 0.45 or $1.2 \mathrm{~m}$ apart within rows and $3.0 \mathrm{~m}$ apart between rows on raised beds $(\approx 0.4 \mathrm{~m}$ high and $0.9 \mathrm{~m}$ wide). Fir sawdust and ammonium sulfate fertilizer $\left(66 \mathrm{~kg} \cdot \mathrm{ha}^{-1}\right.$ of $\left.\mathrm{N}\right)$ was incorporated into the beds before planting and grass alleyways $(\approx 1.1 \mathrm{~m}$ wide) were maintained between bed rows after planting. Each treatment plot consisted of a $6.1-\mathrm{m}$ row of plants and was replicated five times. Treatments were arranged in a randomized complete-block design.

The field was irrigated by overhead impact sprinklers with risers spaced $12.2 \times 12.2 \mathrm{~m}$ apart. Water applications were applied as needed (between May and September) at a rate of 25 to $50 \mathrm{~mm}$ per week. Ammonium sulfate fertilizer was broadcast beneath the canopy each spring (in split applications in April, May, and June) at a rate of 34 to $66 \mathrm{~kg} \cdot \mathrm{ha}^{-1}$ of $\mathrm{N}$ during the first 3 years after planting and $90 \mathrm{~kg} \cdot \mathrm{ha}^{-1}$ of $\mathrm{N}$ thereafter. Weeds, insects, and diseases were controlled with herbicides and pesticides as needed. Plants were pruned each year following standard commercial practices (Strik et al., 1993) and fruit were hand-picked beginning the third year after planting.

Measurements. All measurements were made in 2003 or 2004 at 4 and 5 years after planting. Reference evapotranspiration and precipitation were obtained from a U.S. Bureau of Reclamation AgriMet weather station located less than $1 \mathrm{~km}$ from the site. Irrigation was monitored using a turbine water meter (model W-120; Invensys Metering Systems, Uniontown, Pa.) installed at the inflow of the irrigation system.

Canopy light interception was measured periodically in each plot using a line quantum sensor (model LI-191SA; LI-COR Inc., Lincoln, Neb). Measurements were made on clear days in light conditions ranging from 1680 to $1800 \mu \mathrm{mol} \cdot \mathrm{m}^{-2} \cdot \mathrm{s}^{-1}$ photosynthetic photon flux density. The sensor was positioned beneath the plant canopy, at ground level and perpendicular to the row, between 1200 and $1300 \mathrm{HR}$. Readings were taken on both sides of the row in 75-mm increments from the base of one randomly selected plant to half the distance of an adjacent plant and then averaged and divided by above-canopy readings to estimate the percent light intercepted by the crop canopy. Canopy cover within the grass alleyways was always greater than $90 \%$.

Soil water content was measured using a calibrated neutron probe (503-DR Hydroprobe; CPN International, Martinez, Calif.) and galvanized steel access tubes installed $1.5 \mathrm{~m}$ deep. One access tube was located in each plot at $\approx 0.25 \mathrm{~m}$ from the base of a plant. Neutron counts (15-s intervals) were made ( $1 \mathrm{~d}$ before irrigation) at each $0.3-\mathrm{m}$ depth increment between 0.15 and $1.05 \mathrm{~m}$ from the soil surface. Crop water use in each plot was calculated periodically (in 2004 only) from changes in water content between irrigations in the top $0.6 \mathrm{~m}$ of the soil profile (estimated root zone) minus any precipitation. Any water loss by deep percolation was accounted for when the amount of irrigation or rain received caused the soil water content to exceed field capacity within the root zone (Allen et al., 1998). Runoff and capillary rise from the groundwater table were considered negligible.

Plant water potential was measured using a pressure chamber (model 600; PMS Instrument Co., Corvallis, Ore.) following the recommendations of Hsiao (1990). Measurements were made at midday, between 1330 and $1530 \mathrm{HR}$, on shaded leaves enclosed at least $1 \mathrm{~h}$ in plastic bags laminated with aluminum foil. A preliminary study indicated that water potential of bagged leaves was less variable within the plant than that of exposed leaves and was therefore a more sensitive indicator of water status of the plants (McCutchan and Shackel, 1992).

In Feb. 2003 (beginning of the study) and Jan. 2005 (end of the study), one plant was excavated from each plot, washed free of any soil, and divided into shoot, crown, and roots. Each component was then dried for at least 1 week at $70{ }^{\circ} \mathrm{C}$ and weighed. Before washing, root system diameter was also measured in 2005 to estimate the total root volume in each treatment. Soil cores were collected in July $2004, \approx 0.25 \mathrm{~m}$ from the crown, to determine root length distribution in each treatment. Four cores $(5 \mathrm{~cm}$ diameter) were extracted from each plot, in $0.1-\mathrm{m}$ increments, to a depth of $0.6 \mathrm{~m}$. Roots were washed from the cores, imaged using a flatbed scanner, and measured for length and diameter using image analysis software (WinRhizo v. 4.0; Regent Instruments, Quebec). Root length was divided by soil volume to calculate root length density.

STATistical ANALYSis. Data were analyzed by analysis of variance using PROC GLM in SAS (SAS Institute, Cary, N.C.). Main treatment effects included cultivar and plant spacing; time was also included with repeated measurements on canopy light interception, plant water potential, and soil water content, and depth was included with root length density measurements. Means with significant main effects or interactions were separated at 5\% level of significance using Duncan's multiple range test. Relationships between plant water potential and soil water content were evaluated using nonlinear regression functions in SigmaPlot (version 8.0; SPSS, Chicago).

\section{Results}

IRRIGATION SCHEDULING. Irrigation was applied 13 May to 25 Sept. 2003 and 6 Apr. to 3 Sept. 2004 during dry spring and summer months (Fig. 1). The total amount of water applied 

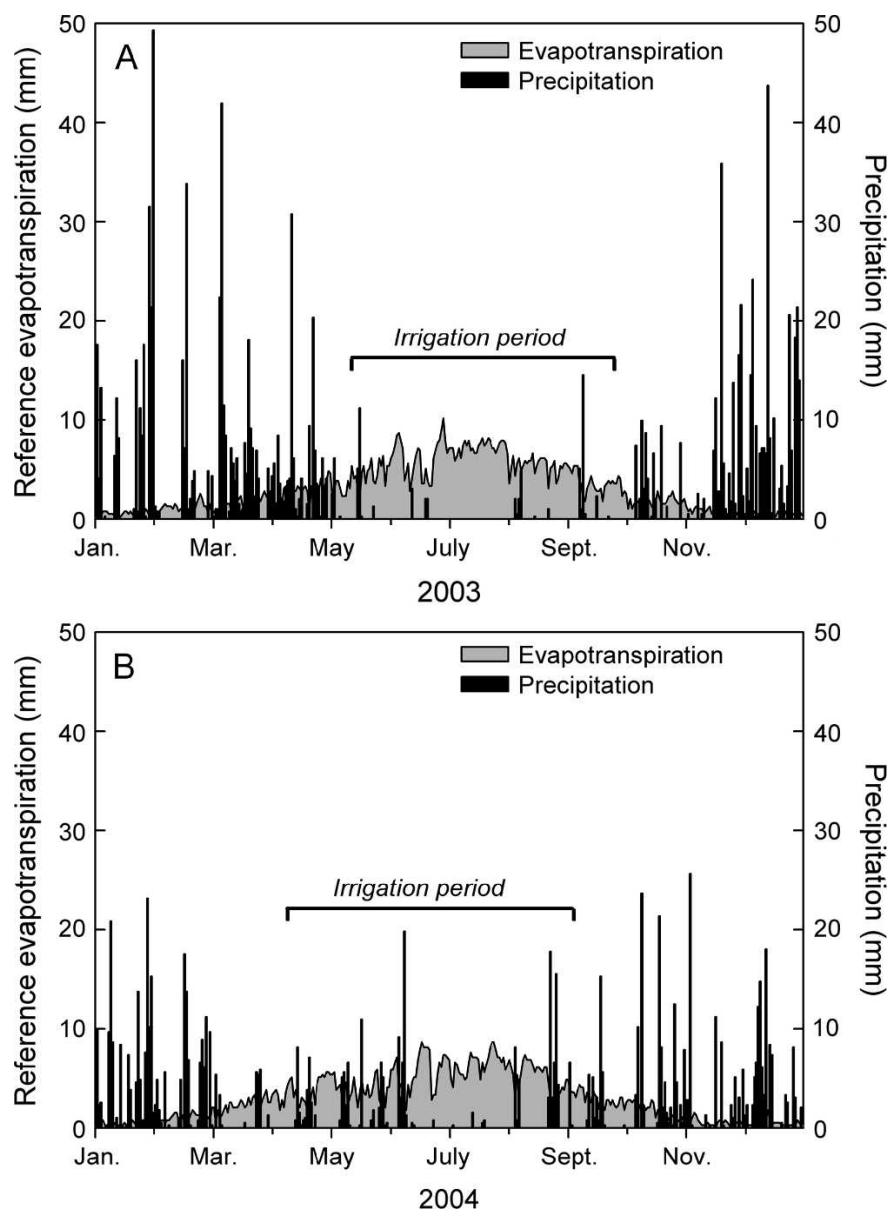

Fig. 1. Reference evapotranspiration and precipitation at Aurora, Ore., in (A) 2003 and (B) 2004. Measurements were downloaded daily from an AgriMet weather station. The horizontal brackets identify when irrigation was applied during the study.

during these periods was 761 and $733 \mathrm{~mm}$, respectively. Precipitation contributed an additional $36 \mathrm{~mm}$ of water as effective rainfall in 2003 and $145 \mathrm{~mm}$ in 2004. Irrigation was scheduled every 3 to $4 \mathrm{~d}$ in 2003 (which is common practice when using overhead sprinklers on blueberry in the Pacific northwestern United States), but only every $7 \mathrm{~d}$ (when needed) in 2004. Less frequent irrigations were used the second year to improve estimates of crop water uptake and to determine its effect on the development of plant water stress.

Plant Size, CANOPY Light interception, AND RoOT Length Distribution. Plants spaced at $0.45 \mathrm{~m}$ tended to produce less biomass per plant but significantly more biomass per hectare than plants spaced at $1.2 \mathrm{~m}$ (Table 1). Plants at $0.45 \mathrm{~m}$ likewise produced more canopy cover per hectare, significantly increasing total light interception of each cultivar by $51 \%$ to $132 \%$ in 2003 and $22 \%$ to $246 \%$ in 2004 (Fig. 2). Light interception generally differed little among the cultivars, which was at least partly attributed to the fact that although 'Bluecrop' usually produced less dry weight than 'Duke' or 'Elliott', it had a higher above- to below-ground dry weight ratio (Table 1).

Significant interactions were apparent between cultivar and spacing treatments on individual plant dry weight and plant dry weight per hectare in Feb. 2005 (Table 1). The interaction indicates that at some point during the study, spacing effects on plant growth began to differ among cultivars. Overall, spacing at $0.45 \mathrm{~m}$ reduced dry weight of individual plants by $36 \%$ in 'Bluecrop' and $56 \%$ in 'Elliott', but only 9\% in 'Duke'. Consequently, total dry weight per hectare at high density increased the most in 'Duke', which increased by $142 \%$, and the least in 'Elliott', which increased by only $16 \%$.

Root length density measured near the plants differed significantly among cultivars and soil depths but not between spacing treatments or any of its interactions (Fig. 3). Each cultivar produced a dense, shallow root system with almost all roots distributed less than $0.4 \mathrm{~m}$ deep. Most roots were very fine, as is typical in blueberry, averaging only 0.18 to $0.20 \mathrm{~mm}$ in diameter. Root diameter increased significantly with soil depth $(P<0.001)$ but was similar among cultivars and plant spacings (data not shown). In general, 'Elliott' produced the largest root volume with the mean \pm 1 standard error averaging $0.18 \pm 0.03 \mathrm{~m}^{3}$ at $0.45 \mathrm{~m}$ and $0.42 \pm 0.06 \mathrm{~m}^{3}$ at $1.2 \mathrm{~m}$, whereas 'Bluecrop' produced the smallest, averaging $0.14 \pm 0.03 \mathrm{~m}^{3}$ at $0.45 \mathrm{~m}$ and $0.26 \pm 0.05$ at $1.2 \mathrm{~m}$.

Crop Water USE aNd its Relation to Plant Water POTENTIAL. Crop water use was significantly higher $(P<0.05)$ when plants were spaced at $0.45 \mathrm{~m}$ than at $1.2 \mathrm{~m}$, although only at certain times and only by $10 \%$ or less over the entire season (Fig. 4A-C). 'Duke' acquired the most water among cultivars, using 5 to $10 \mathrm{~mm} \cdot \mathrm{d}^{-1}$ from mid-May to mid-August, whereas 'Elliott' acquired the least, using only 3 to $5 \mathrm{~mm} \cdot \mathrm{d}^{-1}$. Water use by 'Bluecrop' was intermediate. Water use was highest during fruit filling and ripening but declined markedly after harvest, especially in the early-season cultivar, 'Duke' (Fig. 4A). A sharp decline in water use was less apparent in 'Elliott', which had the latest and most extended fruiting period, ripening from late July to early August (Fig. 4C).

Water demands during fruit ripening were well reflected in plant water potentials of each cultivar. In each case, water potential decreased until harvest and then increased afterward and was significantly lower $(P<0.001)$ when plants were spaced at $0.45 \mathrm{~m}$ than at $1.2 \mathrm{~m}$ (Fig. 4D-F). Water potential declined the most in 'Elliott', decreasing from -0.4 to $-0.5 \mathrm{MPa}$ in late spring to -1.4 to $-1.6 \mathrm{MPa}$ by harvest in mid-July (Fig. 4F). Changes were smaller in the other two cultivars, changing by 0.4 to $0.7 \mathrm{MPa}$ over the season in 'Duke' and only by 0.3 to $0.6 \mathrm{MPa}$ in 'Bluecrop'. However, 'Bluecrop' had the lowest water potential among the cultivars in both spring and fall (Fig. 4E). Similar changes in plant water potential were observed in 2003 as 2004, although differences between treatments were much less apparent in 2003 as a result of more frequent irrigations that year (data not shown).

The effect of less frequent irrigation on plant water potential is illustrated in Figure 5. Whether measurements were taken in June, July, or August, water potential dropped only slightly within the first 3 to $4 \mathrm{~d}$ after irrigation, but declined substantially, in many cases, after 5 to $7 \mathrm{~d}$ without irrigation (Fig. $5 \mathrm{~A}-\mathrm{C})$. This later decline was associated with reduced rates of root water uptake indicated by smaller changes in soil water content in each treatment (Fig. 5D-F). Within cultivars, the most apparent decline in water potential occurred when fruit were in their final stages of ripening, just before harvest.

Soil water content within the root zone was significantly lower at $0.45 \mathrm{~m}$ than at $1.2 \mathrm{~m}(P<0.001)$, even within a day after irrigation was applied (Fig. 5D-F), or when irrigation was applied more frequently (i.e., 2003; data not shown). Apparently, less irrigation water (or rain) was penetrating the canopy 
Table 1. Individual plant dry weight, plant dry weight per hectare, and above- to below-ground dry weight ratio of 'Duke', 'Bluecrop', and 'Elliott' blueberry plants spaced 0.45 or $1.2 \mathrm{~m}$ apart within rows ${ }^{\mathrm{z}}$.

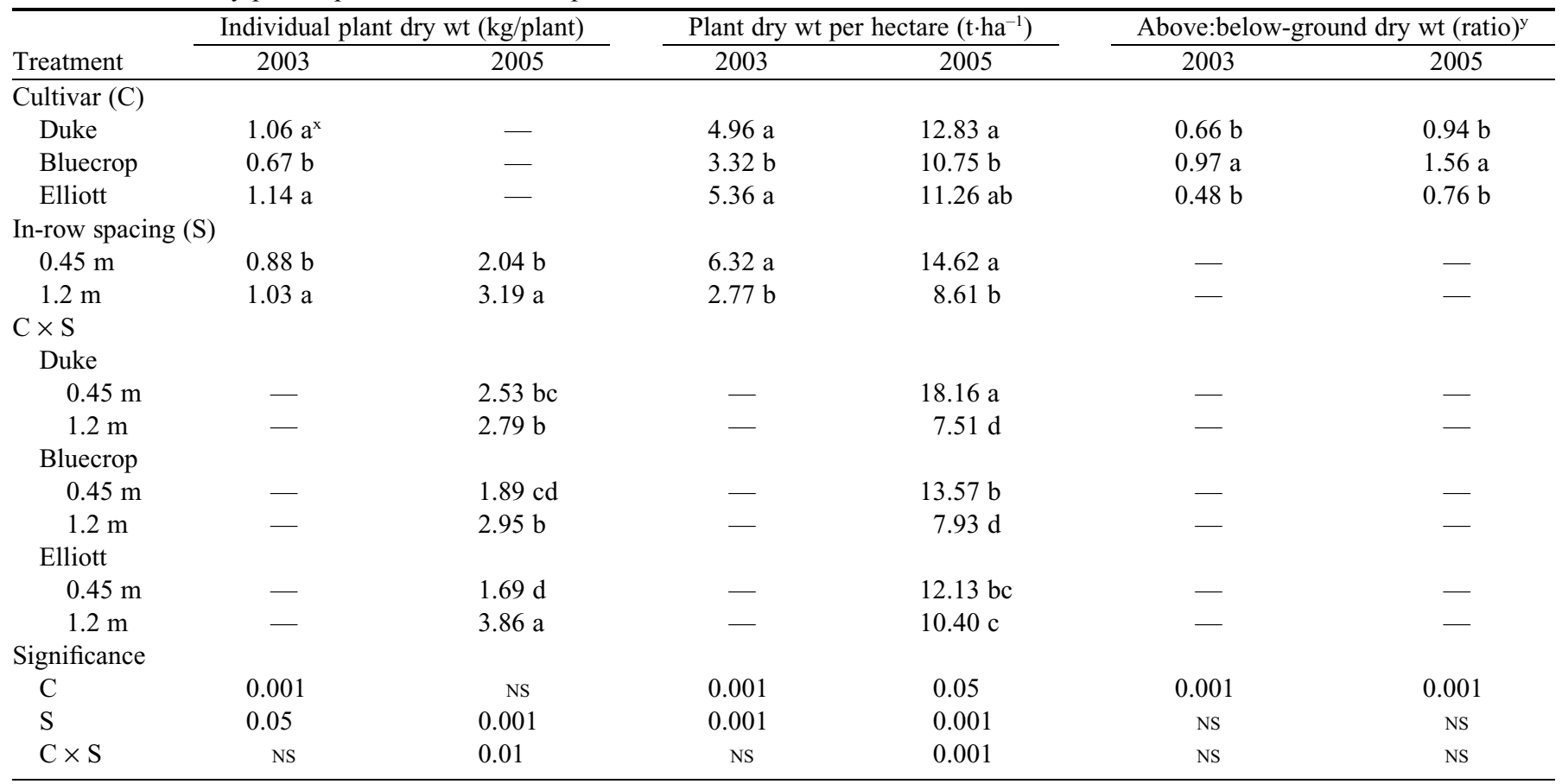

zPlants were established in Oct. 1999. Dry weights were determined in Feb. 2003 (beginning of the study period) and Jan. 2005 (end of the study period).

${ }^{y}$ Calculated as plant dry weight above-ground divided by its dry weight (including the crown) below-ground.

${ }^{\mathrm{x}}$ Cultivars, spacings, and cultivar $\times$ spacing interactions followed by different letters within a given year were significantly different at $P \leq 0.05$ according to Duncan's multiple range test.

${ }^{\mathrm{N}}$ Nonsignificant.

in plants spaced at $0.45 \mathrm{~m}$, thus potentially exposing them to more water stress between irrigations. However, plants at $0.45 \mathrm{~m}$ maintained higher water potentials at lower soil water contents (Fig. 6), thus indicating they extracted more water from drying soil. Among the cultivars, soil water content within a given spacing treatment was usually highest after irrigation in 'Duke' and always lowest in 'Elliott' (Fig. 5D-F). However, 'Duke' and 'Elliott' maintained similar water potentials as soil

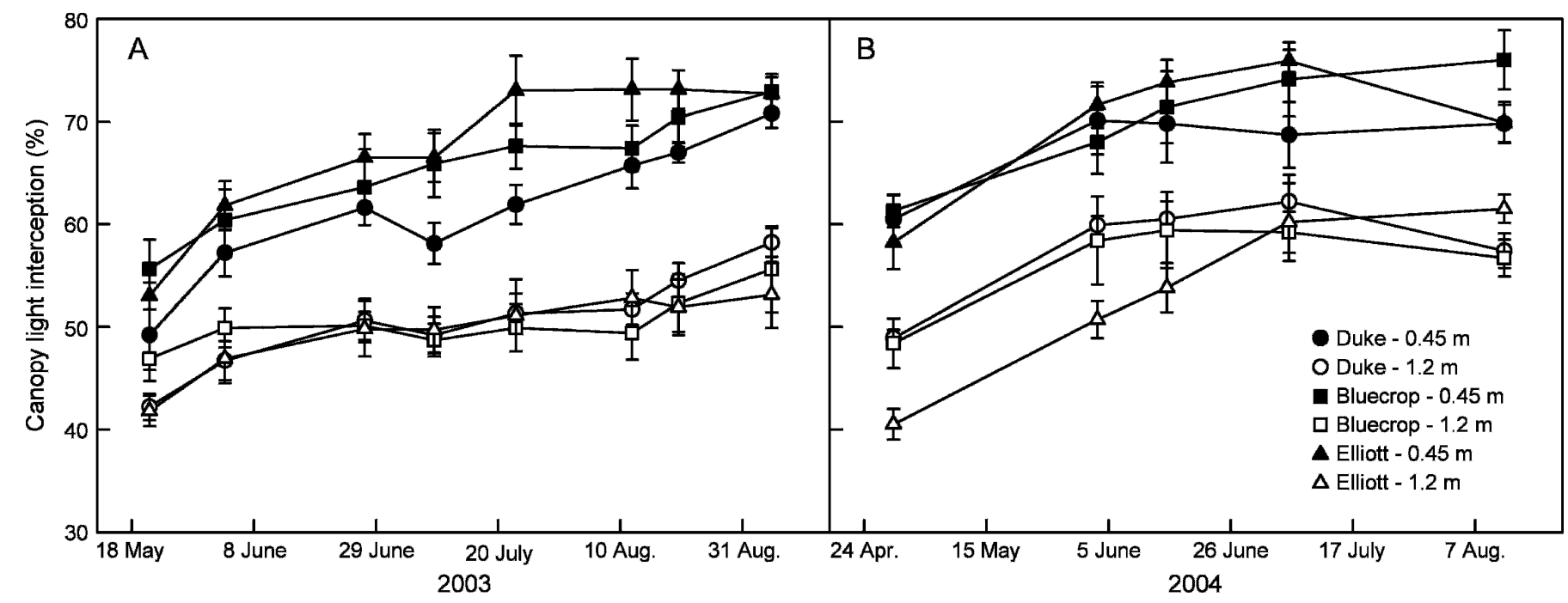

Fig. 2. Canopy light interception of 'Duke', 'Bluecrop', and 'Elliott' blueberry plants spaced 0.45 or $1.2 \mathrm{~m}$ apart within rows. Measurements were taken in (A) 2003 and (B) 2004 during the fourth and fifth growing seasons. Each symbol represents the mean of five plots and error bars represent 1 standard error. According to three-way analysis of variance: cultivar $(P<0.01)$, spacing $(P<0.001)$, time $(P<0.001)$, cultivar $\times$ spacing $(P<0.001)$, and spacing $\times$ time $(P<0.05)$ had significant effects on canopy light interception in 2003; spacing $(P<0.001)$, time $(P<0.001)$, cultivar $\times$ spacing $(P<0.05)$, and cultivar $\times$ spacing $\times$ time $(P<0.05)$ had significant effects on canopy light interception in 2004; all other main effects and interactions were nonsignificant. 


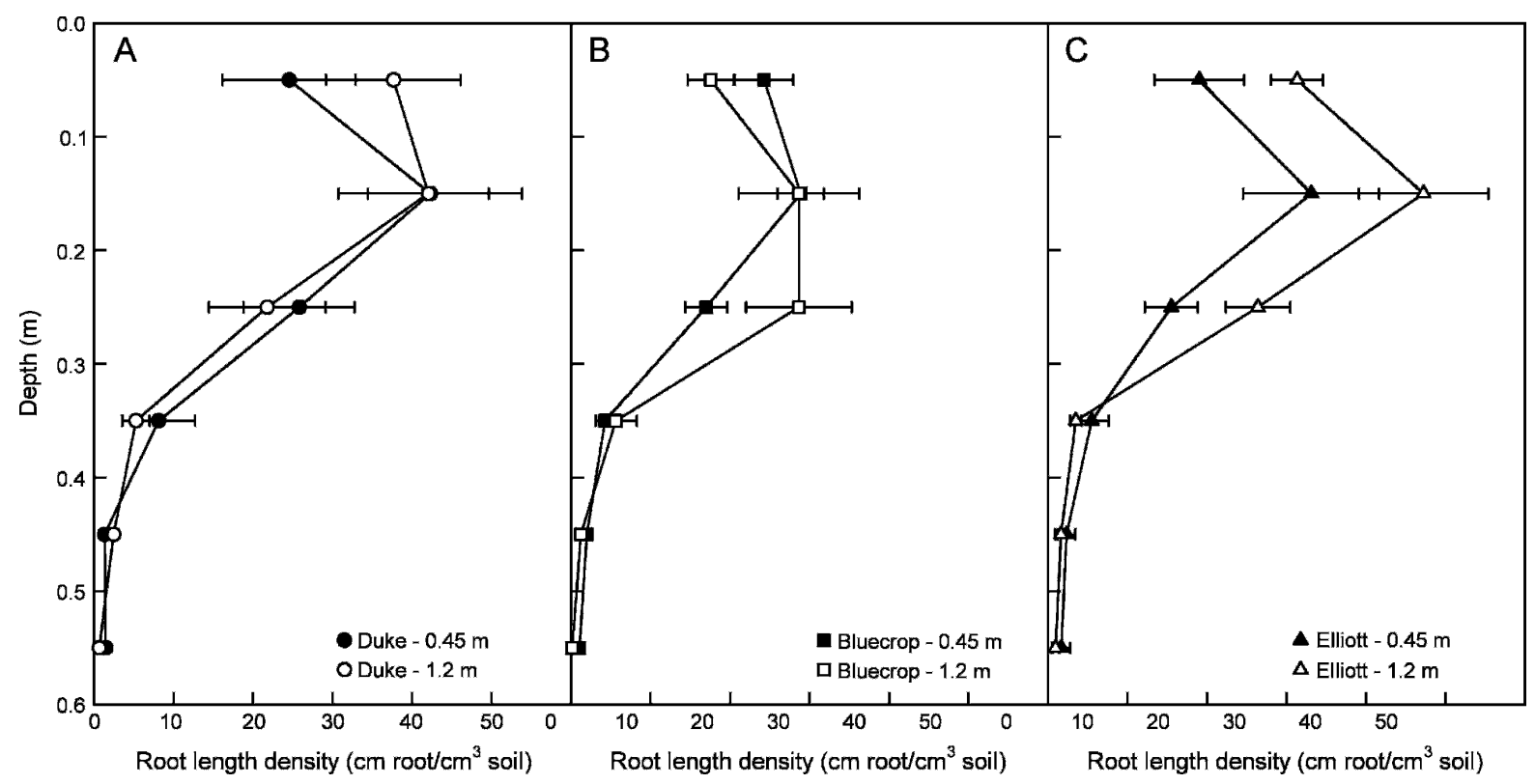

Fig. 3. Root length density of (A) 'Duke', (B) 'Bluecrop', and (C) 'Elliott' blueberry plants spaced 0.45 or $1.2 \mathrm{~m}$ apart within rows. Roots were collected at 0.1 -m depth increments in July 2004 during the fifth growing season. Each symbol represents the mean of five plants and error bars represent 1 standard error. According to three-way analysis of variance: only cultivar $(P<0.001)$ and depth $(P<0.001)$ had significant effects on root length density; spacing and all interactions were nonsignificant.

water was depleted and higher water potentials than those maintained by 'Bluecrop' (Fig. 6).

Fruit PRODUCTION AND WATER USE EFFiCIENCY. Planting at high density significantly increased yield per hectare by $29 \%$ to $111 \%$, depending on cultivar and year, without causing any significant reductions in berry weight (Table 2). It also increased water use efficiency significantly (Table 2). With each cubic meter of water used by the crop in 2004, plants produced, on average, $0.61 \mathrm{~kg}$ more fruit per hectare at $0.45 \mathrm{~m}$ than at $1.2 \mathrm{~m}$. Among cultivars, water use efficiency was similar between 'Bluecrop' and 'Elliott' but lower in 'Duke'.

\section{Discussion}

High-density planting increased both canopy cover and water use in this study, which was more or less expected considering that water use often increases as a function of the canopy in many crops, including blueberry (Holzapfel et al., 2004). However, what was somewhat surprising was that although percent canopy cover increased by as much as $246 \%$ at $0.45 \mathrm{~m}$ than at $1.2 \mathrm{~m}$, water use increased by no more than $10 \%$. Storlie and Eck (1996) found in 6-year-old 'Bluecrop' plants that the ratio between crop and reference evapotranspiration, often referred to as the crop (water use) coefficient, was equal to 1.5 times the canopy coverage. Based on this estimate, water use in 2004 should have differed between planting densities by 88 to $148 \mathrm{~mm}$, depending on cultivar, which is 28 to $113 \mathrm{~mm}$ more than the difference that was actually measured in our study.

Although the small difference we observed in water use may be somewhat attributed to limitations in the methods, similar discrepancies between plant cover and water use have been reported in other crops (Doorenbos and Pruitt, 1977). For example, Stern (1965) observed no discernible differences in evapotranspiration in mature safflower (Carthamus tinctorius L.) plants grown at densities ranging from 25 to 1120 plants $/ \mathrm{m}^{2}$. Apparently, once a crop reaches its effective full cover, which typically happens when the average fraction of the ground shaded by vegetation within a given area reaches $\approx 0.7$ to 0.8 (Allen et al., 1998), a more or less constant proportion of the incident energy load or net radiation is dissipated as latent heat so that any additional increase in plant size has no further effect on total transpiration (Slatyer, 1964). In the present study, maximum summertime canopy cover (including that covered by the grass alleyway between rows) at $0.45 \mathrm{~m}$ ranged from $57 \%$ to $73 \%$ within 4 years after planting and $68 \%$ to $76 \%$ the next year, well within a range at which further increases in plant size would be expected to have little to no effect on the crop water requirements. Conversely, canopy cover was significantly less at $1.2 \mathrm{~m}$, potentially causing what is called a "clothesline effect," a condition in which hot, dry air passing between the plants increases transpiration (Ritchie and Johnson, 1990). Fereres et al. (1982) reported that water use by young almond [Prunus dulcis (Mill.) D.A. Webb] trees was nearly equal to that of a mature orchard after only $50 \%$ canopy coverage was reached. Green et al. (2003) likewise reported that water use by smaller 'Braeburn' apple [Malus sylvestris (L.) Mill. var. domestica (Borkh.) Mansf.] trees spaced at high density were similar to larger 'Splendour' apple trees spaced further apart despite more than a fourfold difference in total leaf area between them.

Less-than-expected water use at high density may have also been the result of more water stress between irrigations in this treatment. Within a few days after irrigation, plant water potentials were generally lower when plants were spaced at $0.45 \mathrm{~m}$ than at $1.2 \mathrm{~m}$. Lower water potentials were mostly attributed to the fact that high-density planting produced a much denser canopy than traditional spacing, deflecting more water away from the roots during sprinkler irrigations (or when 


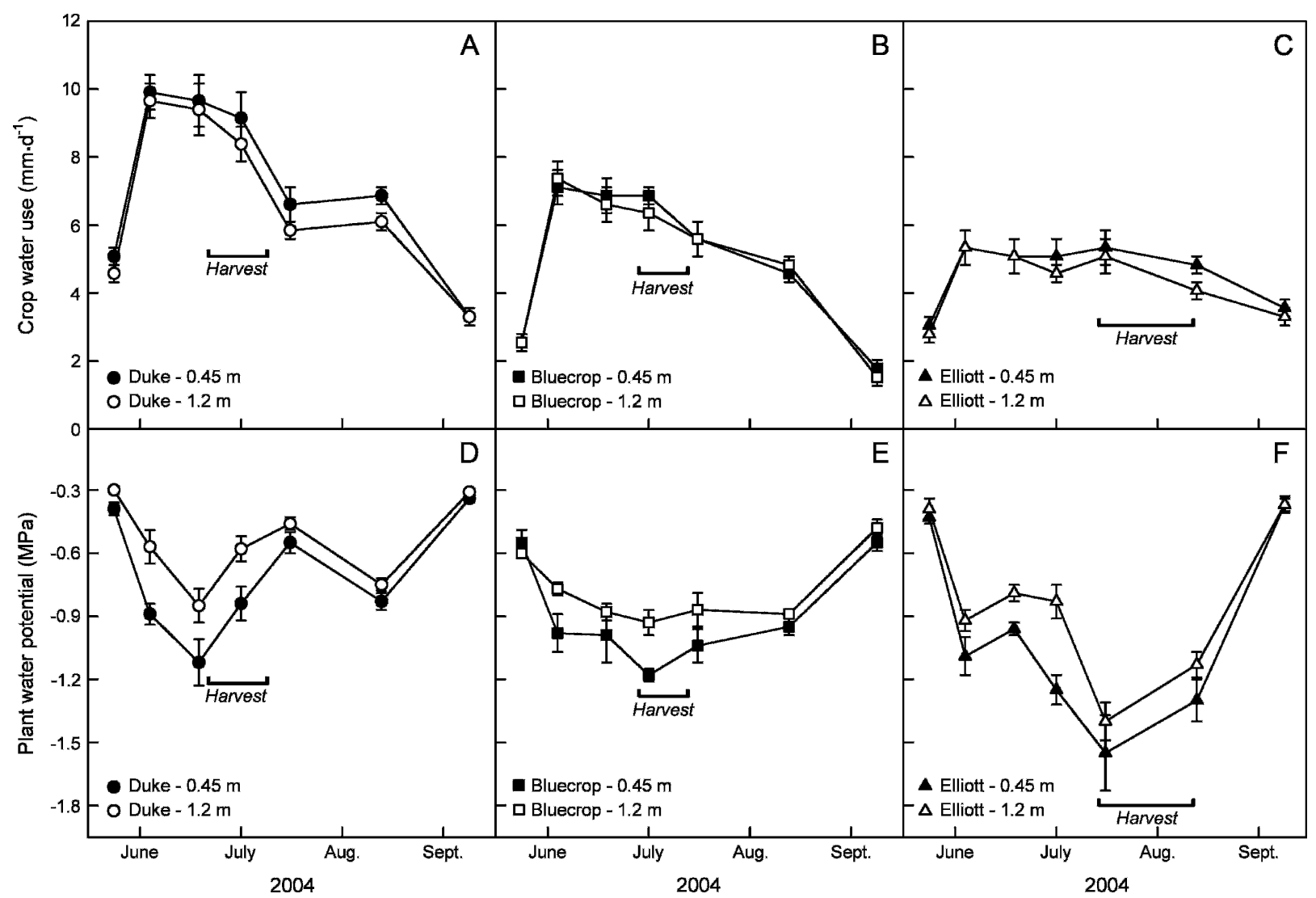

Fig. 4. Seasonal changes in (A-C) crop water use and (D-F) plant water potential in (A, D) 'Duke', (B, E) 'Bluecrop', and (C, F) 'Elliott' blueberry plants spaced 0.45 or $1.2 \mathrm{~m}$ apart within rows. Measurements were taken in 2004 during the fifth growing season. Each symbol represents the mean of five plants and error bars represent 1 standard error. According to three-way analysis of variance: cultivar $(P<0.001)$, spacing $(P<0.05)$, time $(P<0.001)$, and cultivar $\times$ time $(P<0.001)$ had significant effects on crop water use; cultivar $(P<0.001)$, spacing $(P<0.001)$, time $(P<0.001)$, cultivar $\times$ time $(P<0.001)$, and spacing $\times$ time $(P<0.01)$ had significant effects on plant water potential; all other interactions were nonsignificant.

it rained) and leaving less available for uptake. Blueberry is fairly sensitive to water stress and is capable of quickly limiting its transpirational water losses during soil water deficits (Améglio et al., 1999). We previously found that regardless of plant spacing and cultivar, $g_{\mathrm{S}}$ in highbush blueberry decreased almost immediately as water potentials approached values as high as -0.6 to $-0.8 \mathrm{MPa}$ (Bryla and Strik, 2006). In France, mature 'Bluecrop' blueberries exposed to drought closed their stomates and reduced transpiration gradually within $9 \mathrm{~d}$ after withholding irrigation (Améglio et al., 2000). On rewatering, recovery was slow, taking $g_{\mathrm{S}}$ and transpiration 7 to $9 \mathrm{~d}$ to return to normal. A vulnerability curve presented in the same study indicated that embolism in the xylem vessels was negligible when leaf water potential was $-1.2 \mathrm{MPa}$ or higher but increased rapidly at lower water potentials. To develop the curve, hydraulic conductance was measured at different applied pressures on 2- to $3-\mathrm{cm}$-long stem segments excised under water (Sperry et al., 1988). Percent loss of hydraulic conductance was $50 \%$ at $-1.4 \mathrm{MPa}$ and $100 \%$ at $-2.1 \mathrm{MPa}$. However, in situ embolism measured during actual water stress was usually less than $30 \%$. Apparently, rapid reduction in $g_{\mathrm{S}}$ reduced water loss and maintained water potential at the threshold of cavitation in 'Bluecrop', protecting it from total xylem cavitation and enhancing its ability to recover from drought. Plant water potentials in the present study were certainly well within the range to induce stomatal closure at either spacing after only a few days without rain or irrigation and in some cases may have even been low enough to induce cavitation.

Within each cultivar, the most apparent decline in water potential occurred when fruit were in their final stages of ripening, just before harvest. We attributed the differences in water potential to seasonal variation in water use among the cultivars. As mentioned, water use was highest in 'Duke', which ripened first, and lowest in 'Elliott', which ripened last, suggesting that water requirements are higher in early-season than in late-season cultivars. Perhaps cultivars that ripen earlier have higher photosynthetic demands, requiring them to have higher rates of $g_{\mathrm{S}}$ and consequently more water loss. Higher $g_{\mathrm{S}}$ and water use have been associated with increased photosynthetic activity during fruit ripening in lowbush blueberry $(V$. angustifolium Ait.) (Hicklenton et al., 2000). However, it is important to point out that 'Elliott', which produced the densest canopy, also had less water penetrating its root zone during rain and irrigation, potentially leading to more water stress (a supposition supported by lower stem water potentials) and less water loss resulting from increased stomatal closure.

Although water use efficiency was only calculated for one season, the results indicate that spacing plants closer together may significantly increase water use efficiency in blueberry, at least during the first few years after planting when plants are still maturing. At high density, smaller spacing between plants means more water is applied to the roots (rather than between 


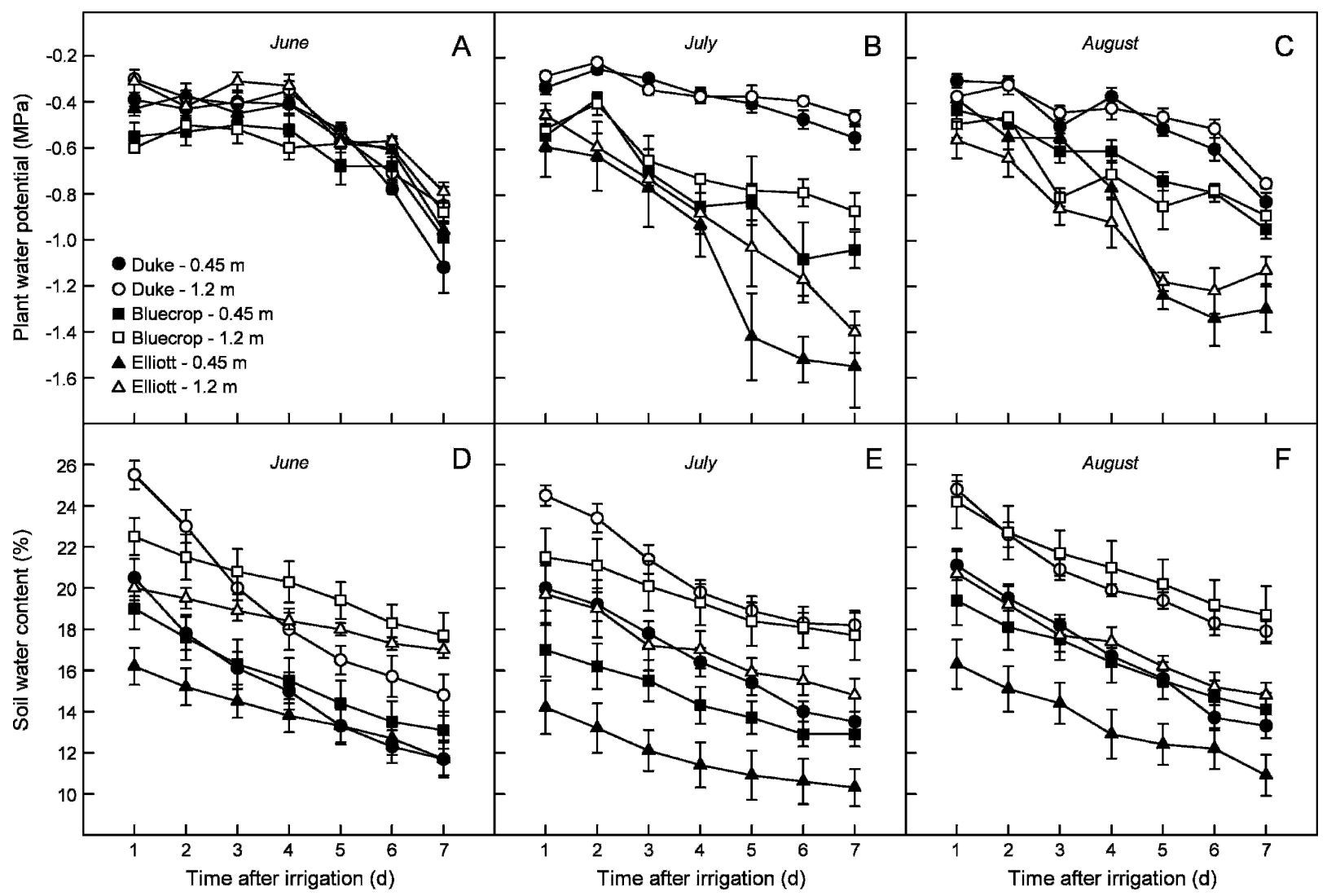

Fig. 5. Daily changes in (A-C) plant water potential and (D-F) soil water content at 0 to $0.6-\mathrm{m}$ depth in (A, D) 'Duke', (B, E) 'Bluecrop', and $(\mathbf{C}, \mathbf{F})$ 'Elliott' blueberry plants spaced 0.45 or $1.2 \mathrm{~m}$ apart within rows. Measurements were made (A, D) 10 to 16 June, (B, E) 10 to 16 July, and (C, F) 7 to 13 Aug. 2004 (year 5 ) beginning $1 \mathrm{~d}$ after an irrigation event each month. Each symbol represents the mean of five plants and error bars represent 1 standard error. According to threeway analysis of variance: spacing $(P<0.01)$, time $(P<0.001)$, and spacing $\times$ time $(P<0.05)$ had significant effects on plant water potential in June; cultivar $(P<$ $0.001)$, spacing $(P<0.001)$, time $(P<0.001)$, cultivar $\times$ spacing $(P<0.05)$, and cultivar $\times$ time $(P<0.001)$ had significant effects on plant water potential in July; cultivar $(P<0.001)$, spacing $(P<0.01)$, time $(P<0.001)$, cultivar $\times$ time $(P<0.001)$, and spacing $\times$ time $(P<0.01)$ had significant effects on plant water potential in August; cultivar $(P<0.001)$, spacing $(P<0.001)$, time $(P<0.001)$, and cultivar $\times$ time $(P<0.001)$ had significant effects on soil water content in June; cultivar $(P<0.001)$, spacing $(P<0.001)$, and time $(P<0.001)$ had significant effects on soil water content in July; cultivar $(P<0.001)$, spacing $(P<0.001)$, and time $(P<0.001)$ had significant effects on soil water content in August; all other main effects and interactions were nonsignificant.

plants), and less is lost to evaporation as a result of more shading of the soil surface (Ritchie and Johnson, 1990). Water use efficiency also differed among cultivars with both 'Bluecrop' and 'Elliott' having higher efficiency than 'Duke'. With growing demands for water worldwide, selecting cultivars and production practices with high water use efficiency will become increasingly important. Depending on how long yield and water use efficiency are positively affected, high-density planting

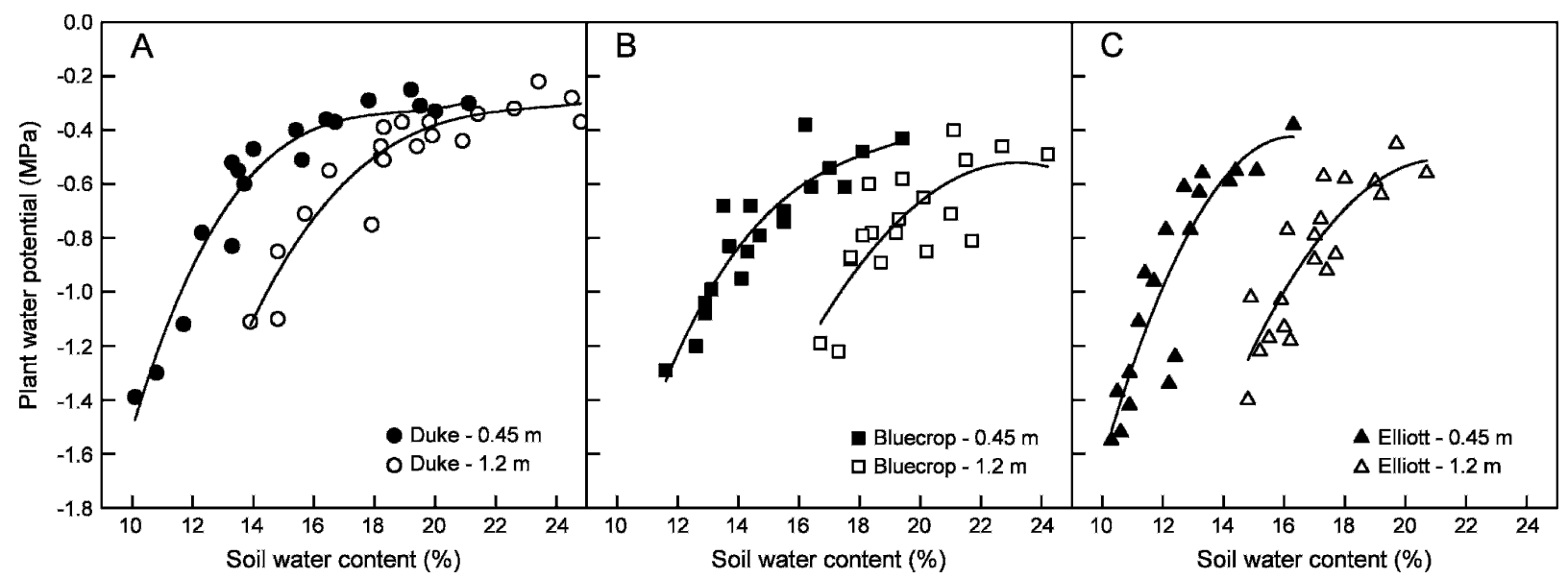

Fig. 6. Relationship between plant water potential and soil water content in (A) 'Duke', (B) 'Bluecrop', and (C) 'Elliott' blueberry plants spaced 0.45 or $1.2 \mathrm{~m}$ apart within rows. Data are the same as those shown in Figure 5 and were fit using quadratic ['Bluecrop' at $1.2 \mathrm{~m}\left(r^{2}=0.63\right)$; 'Elliott' at $0.45\left(r^{2}=0.81\right)$ and $1.2 \mathrm{~m}$ $\left(r^{2}=0.76\right)$ ] or cubic ['Duke' at $0.45\left(r^{2}=0.93\right)$ and $1.2 \mathrm{~m}$ ] equations. 
Table 2. Fruit production and water use efficiency of 'Duke', 'Bluecrop', and 'Elliott' blueberry plants spaced 0.45 or $1.2 \mathrm{~m}$ apart within rows.

\begin{tabular}{|c|c|c|c|c|c|}
\hline \multirow[b]{2}{*}{ Treatment } & \multicolumn{2}{|c|}{ Berry wt (g) } & \multicolumn{2}{|c|}{ Yield $\left(\mathrm{t} \cdot \mathrm{ha}^{-1}\right)$} & \multirow{2}{*}{$\begin{array}{c}\text { Water use } \\
\text { efficiency }\left(\mathrm{kg} \cdot \mathrm{m}^{-3}\right)\end{array}$} \\
\hline & 2003 & 2004 & 2003 & 2004 & \\
\hline \multicolumn{6}{|l|}{$\overline{\text { Cultivar (C) }}$} \\
\hline Duke & $1.61 \mathrm{a}^{\mathrm{y}}$ & $1.47 \mathrm{~b}$ & $8.3 \mathrm{~b}$ & $10.9 \mathrm{~b}$ & $1.37 \mathrm{~b}$ \\
\hline Bluecrop & $1.80 \mathrm{a}$ & $1.88 \mathrm{a}$ & $12.3 \mathrm{a}$ & $13.8 \mathrm{a}$ & $2.38 \mathrm{a}$ \\
\hline Elliott & $1.28 \mathrm{~b}$ & $1.49 \mathrm{~b}$ & $11.5 \mathrm{a}$ & $13.2 \mathrm{a}$ & $2.48 \mathrm{a}$ \\
\hline \multicolumn{6}{|c|}{ In-row spacing $(\mathrm{S})$} \\
\hline $0.45 \mathrm{~m}$ & - & - & $14.2 \mathrm{a}$ & $14.7 \mathrm{a}$ & $2.38 \mathrm{a}$ \\
\hline $1.2 \mathrm{~m}$ & - & - & $7.2 \mathrm{~b}$ & $10.5 \mathrm{~b}$ & $1.77 \mathrm{~b}$ \\
\hline \multicolumn{6}{|l|}{ Significance } \\
\hline $\mathrm{C}$ & 0.01 & 0.0001 & 0.05 & 0.01 & 0.001 \\
\hline $\mathrm{S}$ & NS & NS & 0.001 & 0.001 & 0.001 \\
\hline $\mathrm{C} \times \mathrm{S}$ & NS & NS & NS & NS & NS \\
\hline
\end{tabular}

${ }^{7}$ Calculated as kilograms of fruit produced per cubic meter of water used by the plants between 17 May to 9 Sept. 2004 .

${ }^{y}$ Cultivars and spacings followed by different letters within a given year were significantly different at $P \leq 0.05$ according to Duncan's multiple range test.

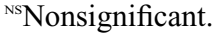

using appropriate cultivars may be a viable strategy to optimize water use in blueberry.

\section{Literature Cited}

Allen, R.G., L.S. Pereira, D. Raes, and M. Smith. 1998. Crop evapotranspiration. Guidelines for computing crop water requirements. Food and Agriculture Organization of the United Nations Irrigation and Drainage Paper 56, Rome, Italy.

Améglio, T., X. Le Roux, M. Mingeau, and C. Perrier. 2000. Water relations of highbush blueberry under drought conditions. Acta Hort. 537:273-278.

Améglio, T., C. Perrier, X. Le Roux, and M. Mingeau. 1999. Drought effects on water relations and fruit yield in highbush blueberry. Fruits 54:423-430.

Anderson, P.C., D.W. Buchanan, and L.G. Albrigo. 1979. Water relations and yields of three rabbiteye blueberry cultivars with and without drip irrigation. J. Amer. Soc. Hort. Sci. 104:731-736.

Buchanan, D.W., F.S. Davis, and A.H. Teramura. 1978. Yield responses of three rabbiteye cultivars to drip irrigation and Vapor Guard. Proc. Fla. State Hort. Soc. 91:162-163.

Bryla, D.R. and B.C. Strik. 2006. Variation in plant and soil water relations among irrigated blueberry cultivars planted at two distinct in-row spacings. Acta Hort. 715:295-300.

Cameron, J.S., C.A. Brun, and C.A. Hartley. 1989. The influence of soil moisture stress on the growth and gas exchange characteristics of young highbush blueberry plants (Vaccinium corymbosum L.). Acta Hort. 241:254-259.

Caruso, F.L. and D.C. Ramsdell. 1995. Compendium of blueberry and cranberry diseases. APS Press, St. Paul, Minn.

Davies, F.S. and D. Wilcox. 1984. Waterlogging of containerized rabbiteye blueberries in Florida. J. Amer. Soc. Hort. Sci. 109:520-524. de Silva, A., K. Patterson, C. Rothrock, and R. McNew. 1999. Phytophthora root rot of blueberry increases with frequency of flooding. HortScience 34:693-695.

Doorenbos, J. and W.O. Pruitt. 1977. Guidelines for predicting crop water requirements. Food and Agriculture Organization of the United Nations Irrigation and Drainage Paper 24 (revised), Rome, Italy.

Erb, W.A., A.D. Draper, and H.J. Swartz. 1991. Combining ability for canopy growth and gas exchange of interspecific blueberries under moderate water deficit. J. Amer. Soc. Hort. Sci. 116: $569-573$.
Fereres, E., D.A. Martinich, T.M. Aldrich, J.R. Castel, E. Holzapfel, and H. Schulbach. 1982. Drip irrigation saves money in young almond orchards. Calif. Agr. 36:12-13.

Green, S., K. McNaughton, J.N. Wünsche, and B. Clothier. 2003. Modeling light interception and transpiration of apple tree canopies. Agron. J. 95:1380-1387.

Haman, D.Z., A.G. Smajstrla, R.T. Pritchard, and P.M. Lyrene. 1997. Response of young blueberry plants to irrigation in Florida. HortScience 32:1194-1196.

Hicklenton, P.R., J.Y. Reekie, R.J. Gordon, and D.C. Percival. 2000. Seasonal patterns of photosynthesis and stomatal conductance in lowbush blueberry plants managed in a two-year production cycle. HortScience 35:55-59.

Holzapfel, E.A., R.F. Hepp, and M.A. Mariño. 2004. Effect of irrigation on fruit production in blueberry. Agr. Water Mgt. 67: 173-184.

Hsiao, T.C. 1990. Measurements of plant water status, p. 243-279. In: B.A. Steward and D.R. Nielsen (eds.). Irrigation of agriculture crops. Agron. Monogr. No. 30. ASA-CSSA-SSSA Publ., Madison, Wis.

McCutchan, H. and K.A. Shackel. 1992. Stem-water potential as a sensitive indicator of water stress in prune trees (Prunus domestica L. cv. French). J. Amer. Soc. Hort. Sci. 117:607-611.

Mingeau, M., C. Perrier, and T. Améglio. 2001. Evidence of droughtsensitive periods from flowering to maturity on highbush blueberry. Scientia Hort. 89:23-40.

Moore, J.N., M.V. Brown, and B.P. Bordelon. 1993. Yield and fruit size 'Bluecrop' and 'Blueray' highbush blueberries at three plant spacings. HortScience 28:1162-1163.

Ritchie, J.T. and B.S. Johnson. 1990. Soil and plant factors affecting evaporation, p. 363-390. In: B.A. Steward and D.R. Nielsen (eds.). Irrigation of agriculture crops. Agron. Monogr. No. 30. ASA-CSSASSSA Publ., Madison, Wis.

Slatyer, R.O. 1964. Efficiency of water utilization by arid zone vegetation. Ann. Arid Zone 3:1-12.

Sperry, J.S., R.R. Donnelly, and M.T. Tyree. 1988. A method for measuring hydraulic conductivity and embolism in xylem. Plant Cell Environ. 11:35-40.

Starr, G., R.M. Seymour, F. Olday, and D.E. Yarborough. 2004. Determination of evapotranspiration and drainage in lowbush blueberries (Vaccinium angustifolium) using weighing lysimeters. Small Fruits Rev. 3:273-283.

Stern, W.R. 1965. Evapotranspiration of safflower at three densities of sowing. Austral. J. Agr. Res. 16:961-971.

Storlie, C.A. and P. Eck. 1996. Lysimeter-based crop coefficients for young highbush blueberries. HortScience 31:819-822.

Strik, B., C. Brun, M. Ahmedullah, A. Antonelli, L. Askam, D. Barney, P. Bristow, G. Fisher, J. Hart, D. Havens, R. Ingham, D. Kaufman, R. Penhalgon, J. Pscheidt, B. Scheer, C. Shanks, and R. William. 1993. Highbush blueberry production. Ore. State Univ. Ext. Serv. Pub. PNW 215.

Strik, B. and G. Buller. 2002. Improving yield and machine harvest efficiency of 'Bluecrop' through high-density planting and trellising. Acta Hort. 574:227-231.

Strik, B. and G. Buller. 2005. The impact of early cropping on subsequent growth and yield of highbush blueberry in the establishment years at two planting densities is cultivar dependent. HortScience 40:1998-2001.

Strik, B. and D. Yarborough. 2005. Blueberry production trends in North America, 1992 to 2003 and predictions for growth. HortTechnology 15:391-398.

U.S. Dept. of Agr. 2006. Berry report for Washington and Oregon, Jan. 2006. U.S. Dept. of Agr., Washington, D.C.

Yang, W.Q. 2002. 2001 Highbush blueberry field survey in OregonCultural practices. Proc. Ore. Hort. Soc. 91:162-163.

Yuste, J., J.A. Rubio, and M.A. Pérez. 2004. Influence of planting density and water regime on soil water use, water relations and productivity of trellis-trained Tempranillo grapevines. Acta Hort. 646:187-193. 